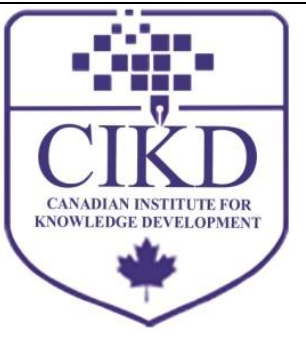

\title{
Linking Workplace Deviance and Abusive Supervision: Moderating Role of Positive Psychological Capital
}

\author{
Basharat Raza $^{1 *}$, Alia Ahmed ${ }^{2}$, Sabahat Zubair ${ }^{3}$, Abdul Moueed ${ }^{4}$ \\ ${ }^{1}$ National College of Business Administration \& Economics, Lahore, Pakistan \\ ${ }^{2}$ Business School of Management Sciences, National College of Business Administration \& Economics, \\ Lahore, Pakistan \\ ${ }^{3}$ MBA, National College of Business Administration \& Economics, Lahore, Pakistan \\ ${ }^{4}$ National College of Business Administration \& Economics, Lahore, Pakistan
}

\section{Keywords: \\ Workplace deviance, \\ Supervisor directed \\ Deviance, Organization directed deviance, Abusive supervision, Positive psychological capital}

\section{Received}

14 October 2018

Received in revised form 10 March 2019

Accepted

11 March 2019

Correspondence:

basharat.hailians@gmail.com

\section{Abstract}

\begin{abstract}
Workplace deviance is one of the undesirable behaviors which is responded by employees due to abusive supervision in the workplace. Abusive supervision is one of the crucial topics in the knowledge of the body of management literature. The employees display aggression and retaliation behavior against supervisor interpersonal mistreatment, and ultimately employees engage with deviant behavior. Psychological capital reduces the effect of workplace deviance in the presence of abusive supervision. This study presents a motivational model of how to decrease the effect of workplace deviance in the presence of abusive supervision. The total sample size was 300 pharmaceutical representatives, and simple random sampling technique was used. The structural equation modelling (SEM) technique was used, and the study found that psychological capital moderates the relationship between abusive supervision and employee workplace deviance. Practical implications give few reasons for abusive supervision and guidelines on how to reduce the influence of deviant behaviors and offer new directions for future research and report unexplored theoretical predictions.
\end{abstract}

(CAIMI Journals

Workplace deviance is one of the undesirable behaviors which is responded by employees. The supervisor's mistreatment and these behaviors are highly harmful to organizations (Aquino, Galperin, \& Bennett, 2004). According to Bennet and Robinson (2003), deviance is a kind of 
destructive behavior in which employees intentionally violate the organization's norms and plan to harm an organization, coworkers or both. Many intellectuals have also reported that workplace deviance negatively impacts on organizations financially and psychologically (Roberts, Scherer, \& Bowyer, 2011; Robinson \& Greenberg, 1998). Job stress, perceived interactional injustice, leader-member exchange, job commitment and satisfaction, organization management style, negative believes on organization, psychological distress, work related negative effects are the prototype of the workplace deviance (Li, Wang, Yang, \& Liu, 2016; Lian, Ferris, Morrison, \& Brown, 2014; Michel, Newness, \& Duniewicz, 2016; Mitchell \& Ambrose, 2007; Park, Hoobler, Wu, Liden, Hu, \& Wilson, 2017; Restubog, Scott, \& Zagenczyk 2011; Thau, Bennett, Mitchell, \& Marrs, 2008; Tepper, Henle, Lambert, Giacalone, \& Duffy, 2008; Wang, Mao, Wu, \& Liu, 2012). Social exchange perspective found support in management literature regarding workplace deviance (Cropanzano \& Mitchell, 2005), because interpersonal mistreatment by supervisor impact badly and distract the relationship of supervisor and employees. Intellectuals evidently found that individual reciprocate retaliation behavior against perceived unfairness in the organization (Greenberg \& Alge, 1998; Skarlicki, Floger, \& Tesluk, 1999), and breach the trust (Bies \& Tripp, 1996; Vander Elst, Cuyper, Baillien, Niesen, \& Witte, 2016) threat to identity (Aquino \& Douglas, 2003). Consequently, some researchers have detached the interpersonal and organizational dimensions of deviant behavior (Diefendorff \& Mehta, 2007; Thau et al., 2008; Tepper et al., 2008) and some take these dimensions jointly (Detert, Trevino, Burris, \& Andiappan, 2007; Hamid, Juhdi, Ismail, \& Abdullah, 2017; Michel et al., 2016). Thus, our focus is on dimensions of deviant behaviors, e.g. organization-directed deviance and supervisory-directed deviance.

Supportive supervision plays an important role in the growth of an organization. Authentic leaders motivate and influence subordinate's psychological state (Wang et al., 2014). Many researchers have identified the various outcomes of managerial coaching such as job performance (Ali, Lodhi, Raza, \& Ali, 2018), organizational citizenship behavior (Raza, Ali, Ahmed, \& Ahmad, 2018; Raza, Ali, Ahmed, \& Moueed, 2017) trustworthiness (Kim \& Kuo, 2015), and thriving at work (Raza, Moueed, \& Ali, 2018). Undeniably, a psychological contract exists between supervisors and subordinates, whenever a contract breach from one side, ultimately organization has to bear heavy cost (Vander Elst et al., 2016). Therefore, their relationship is become more complicated and challenging aspect for an organization because to some extent both display abusive and supportive behavior in the workplace. In last decades, researchers have focused to explore logical reasoning behind harmful, destructive behaviors at workplace and investigate antecedence of supervisory mistreatment, subordinate vengeance, workplace deviance that highly influence organization growth (Mitchell \& Ambrose, 2007; Park et al., 2017; Tepper, 2000; Tepper, Duffy, Hoobler \& Ensley, 2004; Tepper, Duffy \& Shaw, 2001; Tepper et al., 2008; Zellars, Tepper, \& Duffy, 2002).

Supervisor's responsibility is to make strategies on how to train employees, development of an organization and planning to improve organizational functions and performance (Jones, Woods, \& Guillaume, 2016). Ali, Ahmad and Iqbal (2012) found human resource planning for internal and external fit. They are the representatives and main key to connect their subordinates with the organization. Employees display interpersonal relationship because organizational performance depends on it (Mitchell \& Ambrose, 2007). Thus, in this study our 
focus is on the dark side of supervision and employees' outcomes. Globally, abusive supervision is a growing issue in every type of service setting that affects the organization badly. According to Tepper (2000), abusive supervision is "subordinates' perception at the extent to which a supervisor displays undesirable verbal and nonverbal behavior (e.g., yelling, discouragement, loud bursts, publicly humiliation, rudeness), excluding physical contact". Abusive supervision is subjective that means one employee may view supervisor behavior as abusive, another may not (Tepper, 2000). Researchers empirically investigated abusive supervision and its harmful effects. Subordinate outcomes include lessen job commitment and satisfaction (Duffy \& Ferrier, 2003; Tepper et al., 2004; Tepper et al., 2008); increase revengeful behaviors toward organization, supervisors and coworkers (Mitchell \& Ambrose, 2007; Michel, Newness, \& Duniewicz, 2016; Thau et al., 2008); higher turnover, psychological distress (Li, Wang, Yang, \& Liu, 2016; Tepper, 2000); counterproductive actions (Detert et al., 2007). In many empirical types of research, links of abusive supervision and employee's deviance behaviors are well documented in different cultural context (Hamid et al., 2017, Kluemper, Mossholder, Ispas, Bing, Iliescu, \& Ilie, 2018; Martinko, Harvey, Brees \& Mackey, 2013; Wang et al., 2014). Thus, no study has investigated how abusive supervision trigger subordinate's deviant behavior in Pakistani cultural context.

Moreover, psychological capital has been acknowledged as moderator and mediator in many types of research which indicate that employees' resources are most significant to handle uncertainties in the workplace. According to Job Demand-Resources model (Bakker \& Demerouti, 2007), job resources (such as empowerment, task identity, perceived organization support and perceived supervisory support) and psychological capital (self-efficacy, hope, resilience and optimism) are the motivational elements that predict work engagement and enhance employee's performance. Bakker and Demerouti (2007) postulate that job demand creates distress which resultant psychological exhaustion, poor health and anxiety by holding a constant job. In such a case, positive psychological resources prevent the felling of stress and anxiety. Researchers have found the origin of counterproductive working behavior. For example, Fox and Spector (1999) posit that workplace constraints are the primary source of workplace deviance. That means individuals who experience stressor at work environment; they may counteract with workplace deviance. Therefore, Avey, Luthans, and Jensen (2009) argue that PsyCap fight against stressor which creates frustration and anxiety and resultant workplace deviance. Fox and Spector's (1999) process model points that resilience help to prevent the workplace distress, frustration and stressor.

Consequently, a high level of hope helps individuals to find alternative ways to cope with problems which turn as a stressor. Furthermore, optimistic combat against stressor as highly optimistic employee always have positive expectations in the context of future events that will be improved. Prior research indicates that continuous interaction and subsequent exchange relationship and leaders implant positive psychological state into their subordinates (Ilies, Morgeson, \& Nahrgang, 2005).

Authentic leaders can trigger the follower's psychological capacities because they are credibly hopeful and trustworthy (Gardner \& Schermerhorn, 2004). They are able to increase the followers' hope by developing their willpower as well as give the positive direction which increase their sense of self-efficacy (Avolio, Gardner, Walumbwa, Luthans, \& May, 2004). 
Contrary, Li et al. (2016) found that abusive supervision is positively linked with member's psychological distress. Roberts et al. (2011) posits that individuals who have a higher level of psychological capital can easily cope with stressful situations as well as more positively respond rather than negatively. Thus, we choose positive psychological capital as a moderator between abusive supervision and subordinate's deviant behaviors to fill the literature gap. Therefore, the association between abusive supervision, interpersonal deviance, supervisordirected deviance and organizational-directed deviance will be weak when an individual has high psychological capital rather than low.

\section{Theoretical Framework and Hypotheses Development}

Multiple theories (e.g., COR theory, social exchange theory, Fairness theory, reactance theory, Affective event theory, etc.) assist to broadly study the negative impact of abusive supervision and workplace deviance, but we mainly support Social exchange theory and COR theory to conduct the research.

\section{Abusive Supervision and Deviant Behaviors}

The workplace is one of the most challenging platforms for an individual where diversity of destructive attitude and behavior is expressed in different ways that negatively influence the individual's productivity and organization's growth. These undesirable behaviors ultimately violate the set norms and significantly affect the entire organization. Many researchers give different names to these undesirable behaviors and as a construct used in variety of studies like workplace deviance (Robinson \& Bennet, 1995), workplace violence and aggression (Neuman \& Barron, 1998), counterproductive behavior (Detert et al., 2007; Spector, Fox, Penney, Bruursema, Goh, \& Kessler, 2006) and retaliatory behavior (Jones, 2009) which voluntarily disrupt organization's norms as well as sabotage the well-being of the organization, coworkers or both (Robinson \& bennet, 1995). Based on social exchange theory (Blau, 1964), individuals reciprocate positive and negative reactions in the organization. For instance, Colquitt, Conlon, Wesson, Porter, and Ng (2001) found empirical evidence that interactional justice is positively associated with employee's organizational commitment and organizational citizenship behaviors. On the other side, negative reciprocate defined by Cropanzano and Mitchell (2005) as negative treatment returned with negative treatment. Interpersonal mistreatment (supervisory mistreatment) trigger the employee's retaliatory and counterproductive behaviors (Jones, 2009; Mitchell \& Amobrose, 2007). Robinson and Greenberg (1998) posit that interpersonal mistreatment is the main element of abusive supervision as well as a solitary predictor of workplace deviance (Detert et al., 2007) that is harmful for all levels of the organization.

Abusive supervision includes rudeness, hostility, humiliation, publicly criticism, angry and shouting high increase turnover, psychological distress and decrease perceived organizational justice (Restubog et al., 2011; Tepper, 2000). Restubog et al. (2011) empirically tested the argument which is based on transactional theory of stress (Lazarus \& Folkman, 1987) that individuals who experience abusive supervision and become distressed, fearful or anxious will exhibit aggression and violence by engaging in undermining social behavior (e.g., criticizing, demotivate, ignoring), while employees who do not become distressed by supervisory mistreatment they will retaliate against supervisor by engaging in deviant behavior. Thau et 
al.'s (2008) study found that when employees perceive the management style of the organization is higher rather than the low level of uncertainty, the association of abusive supervision and workplace deviance will be stronger. Uncertainty Management Theory explains this relationship in these words, when uncertainty is unified with abusive supervision, employees react more negatively against the organization (Lind \& Van den Bos, 2002).

Social exchange theory provides a better understanding to investigate the linkage between abusive supervision and deviant behavior. Social exchange theory explains when an individual grieves unsuspected punishment, they ultimately engage in aggressive behaviors. Empirical evidence posits that subordinates negatively react to abusive supervision by engaging in deviant behaviors that sabotage organizations and its members (Aquino, Tripp \& Bies, 2006; Mitchell \& Ambrose, 2007; Tepper et al., 2008). Workplace deviance typology established by Robinson and Bennett (1995) is categorized into two types; (a) organizational deviance and (b) interpersonal deviance. Organizational deviance is one of the deviant behaviors that directly harm the organization (e.g., delaying work, sabotage, lateness, stubbornly extend overtime).

Interpersonal deviance is another type of deviant behavior that directly harm the coworkers (e.g., verbal abuse, theft, violence, gossips, sexual harassment). Researcher argue that it is also important to distinct among types of deviance either it is targeted to the organization deviance or interpersonal deviance (Robinson \& Bennett, 1995). Target of deviance is an important component that help to identify the dimension of deviance either individual target to other individual (interpersonal deviance) or to organization (organization deviance) (Bennet \& Robinson, 2000) or to supervisor directed deviance (Wang et al., 2012). Supervisory directed deviant behavior is kind of voluntarily vengeance that employees take from supervisors for their abusive behavior (Skarlicki \& Folger, 2004). Correspondingly, different predictors are expected to influence the targets differently (Hershcovis et al., 2007). We assume that individuals who experience supervisor mistreatment may exhibit deviant behavior and target the organization, its members (co-workers) and their supervisor.

\section{Moderating Role of Psychological Capital}

Undoubtedly, employees rely on organizational resources (e.g., pay, social status, organizational support, information and trust) as well as personal resources (e.g., psychological capital, knowledge, skill and ability) to accomplish their career goals (Foa \& Foa, 1980; Hobfoll, 2001). We use Conservation of Resource theory to analyze positive psychological capital as a moderator among abusive supervision and subordinate's deviant behaviors in our theoretical framework. Wang et al.'s (2012) study indicates that abusive supervision disrupts the employee's psychological state which leads to deviant behaviors. Ashforth's (1997) study suggest that abusive supervision generates employee's feelings of disaffection, frustration, and helplessness. Restubog, et al. (2011) viewed abusive supervision as an external stressor that generates subordinate's negative feelings and thoughts.

According to Conservation of Resources (COR theory), abusive supervision as a kind of undesirable behavior comes from leaders which causes stressful sources for employees that deplete their resources, and has reflective consequences for their health and well-being (Hobfoll, 2001; Restubog, Scott, \& Zagenczyk, 2011). This theory also suggests that depletion in employee's resources is more silent than gain them. Depletion in resources leads to negative 
consequences like work-family conflicts (Carlson, Ferguson, Hunter, \& Whitten, 2012) increase turnover (Halbesleben, 2011), job dissatisfaction (Grandey \& Cropanzano, 1999), and low performance (Wright \& Cropanzano, 1998).

Empirical studies suggest that abusive supervision generally demonstrate subordinate's Somatic anxiety (Rafferty, Restubog, \& Jimmieson, 2010), depression (Haggard, Robert, \& Rose, 2011), psychological distress (Li, Wang, Yang, \& Liu, 2016; Tepper et al., 2007), and anxiety (Hobman, Restubog, Bordia, \& Tang, 2009). Raza et al. (2018) found that the moderating role of work family conflicts between the relationship of trait mindfulness and job satisfaction and turnover intentions. Psychological distress is a kind of mental strain categorized by undesirable thoughts like depression or anxiety (Selye, 1974). These undesirable thoughts and mental strain characteristically cause employee's resource depletion (Byrne et al., 2014). According to COR theory, employees always strive to gain, retain and protect their resources (Hobfoll, 2001). Research shows that individual attributes influence the association of interpersonal mistreatment and negative outcomes ( $\mathrm{Li}$ et al., 2016; Rafferty et al., 2010). Kluemper et al. (2018) found employees with a low level of core-self-evaluation (CSE) sense more abusive supervision and involve in deviant behaviors. CSE contains four core traits like self-esteem, the locus of control, emotional stability and generalized selfefficacy support individuals to function in the workplace (Judge \& Bono, 2001). People vary in their ability to tolerate the negative events in the organization. Individuals who have higher cognitive ability less like to respond to supervisory abuse and engage in workplace deviant behaviors (Kluemper et al., 2018).

We support COR theory (Hobfoll, 2001) and our major focus is on positive PsyCap because it is one of the employee's resources which helps to cope with work environment uncertainties. Psychological capital is considered a multidimensional construct and it is defined as an employee's positive psychosomatic state of development (Luthans, Avolio, Avey, \& Norman, 2007). Basically, it contains four psychological resources: Self-efficacy (having confidence to face any challenging situation), optimism (positive expectations of success), hope (determined toward goals), and resilience (ability to quickly cope with difficulties) (Luthans et al., 2007) that help individuals to accomplish goals and generate positive work-related outcomes, performance and reduce turnover (Avey et al., 2009, Avey Reichard, Luthans, \& Mhatre, 2011). Luthans et al. (2008) found that an employee's PsyCap and supportive climate is positively associated with performance, satisfaction and commitment. Avey et al.'s (2011) meta-analysis indicates that PsyCap is negatively associated with employee's undesirable attitude (stress, anxiety, turnover intention) and undesirable behavior (e.g., deviance), whereas it is positively related to desirable attitude (satisfaction, commitment and wellbeing), employee performance and desirable behavior (organizational citizenship). Newman, Nielsen, Smyth, and Hirst (2018) argue that social support from work domain enhances employee psychological wellbeing through the psychological capital. Li et al. (2016) define psychological capital as an individual's significant specific resource that helps them to effectively cope with interpersonal mistreatment which lessens the negative influence of mental strain. This helps to prevent subordinate to engage with deviant behavior. 


\section{Theoretical Framework}

The theoretical framework is presented in Figure 1:

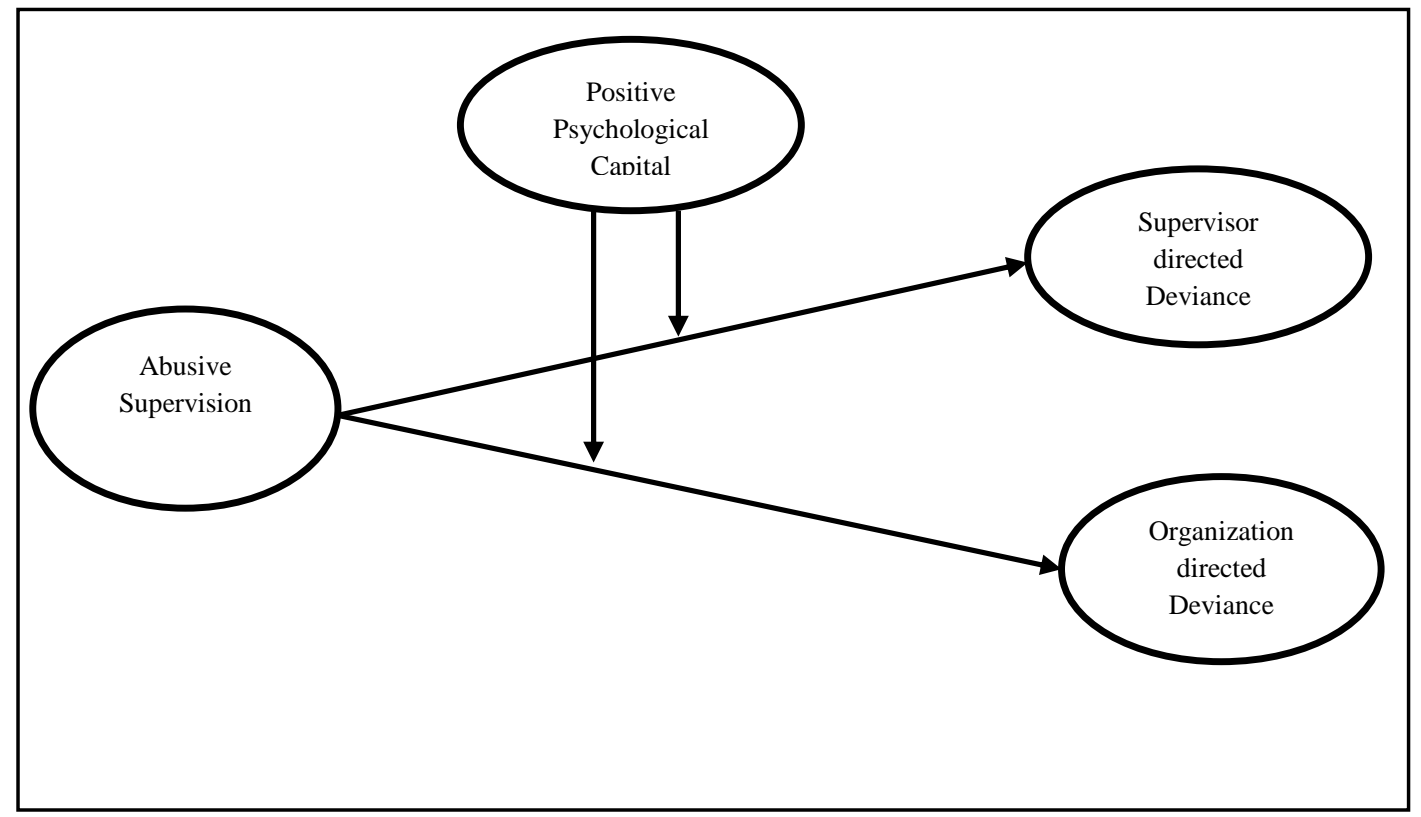

Figure 1. Theoretical framework of the study

\section{Research Questions and Research Hypotheses}

The research questions of the study are:

- What is the relationship of abusive supervision and supervisor directed deviance?

- What is the relationship of abusive supervision and organization directed deviance?

- Does positive psychological capital moderate the relationship of abusive supervision and supervisor directed deviance?

- Does positive psychological capital moderate the relationship of abusive supervision and organizational directed deviance?

Based on literature review, we hypothesize that:

H1: Abusive supervision has a positive association with supervisor directed deviance.

H2: Abusive supervision has a positive association with organizational directed deviance.

H3: Positive psychological capital moderates the association of abusive supervision and supervisor directed deviance as the relationship of abusive supervision and supervisor directed deviance weaken in the presence of positive psychological capital.

H4: Positive Psychological capital moderates the association of abusive supervision and organizational directed deviance as the relationship of abusive supervision and organizational directed deviance weaken in the presence of positive psychological capital.

\section{Method}

\section{Sample and Procedure}

We directly contacted four pharmaceutical organization's human resource managers, they agreed to contribute and influentially respond in our study. Concerning the time horizon, the nature of the study is cross-sectional and quantitative. Our targeted population is from the pharmaceutical industry which is best suitable for this model in term of job requirements and 
culture of the industry. To conduct this study firstly, we arrange a meeting with human resource managers and explain them the study purpose and research methods. With the help of HR departments, a list of 363 subordinates (full-time employees) finalized by using the simple random technique. We distributed questionnaires to participants individually and directly collected via researchers to confirm the confidentiality. Furthermore, we attached a letter with each questionnaire to ensure confidentiality of their responses, the aim of the study, and their participation. Some employees declined to participate so that our sample size shortened to 301 employees. The respondents were $64 \%$ male, $54 \%$ were in the age of $25-30,65 \%$ respondents had master education, and $58 \%$ respondents had job experience of 1-5 years.

\section{Measures}

\section{Abusive Supervision}

Subordinates responded the frequency at which their supervisor abusively behaves. To evaluate this frequency, we used a 15-item scale of Tepper (2000). Sample Items are "My supervisor ridicules me" and "My supervisor does not allow me to interact with my coworkers."

\section{Psychological Capital}

The psychological capital questionnaire contains12 items related to the academic context (Avey et al., 2011). This questionnaire has four dimensions of the psychological capital construct with a Likert-type scale (from 1 agree to 5 disagree). We used three items linked with self-efficacy dimension (e.g. "I feel sure when sharing information about my studies with other people"). Two items linked with optimism dimension (e.g. "Concerning my studies, I'm optimistic about what the future offers me"). Four items linked with hope dimension (e.g. "Right now I see myself as being pretty successful in my studies"). And three items linked with resilience dimension (e.g. "I usually take the stressful aspects of my studies in stride").

\section{Supervisor Directed Deviance}

The frequency at which their subordinates display supervisor directed deviance was measured by 12-items scale of Bennett and Robinson (2000). Sample items contain "Made an obscene comment or gesture toward a supervisor." And "Publicly embarrassed my supervisor."

\section{Organization Directed Deviance:}

The frequency at which their subordinates display organizational directed deviance was measure by 10-items scale of Bennett and Robinson (2000). Sample items are "Put little effort into your work." And "Come in late to work without permission".

\section{Analysis Strategy}

For data analysis, we used SPSS (version 22) and Amos (version 22) with SEM technique. We applied basic statistical tools to generate descriptive statistics results. Measurement mode and structural model are two steps in SEM. We used Measurement model to found convergent validity by average variance extracted (AVE) and discriminant validity that measured by Fornell and Larcker (1981) criterion. Furthermore, we tested hypotheses and mediating effects by using the structural model. 


\section{Results}

\section{Measurement Model}

Measurement model frequently used to evaluate confirmatory factor analysis (Anderson \& Gerbing, 1988). To ensure the validity, confirmatory factor analysis was used. Therefore, we evaluated measurement model by using CFA. Furthermore, the fit indices measurement model was estimated. The results indicated value $\left(\chi^{2}=3118.449, \mathrm{df}=1298, \chi^{2} / \mathrm{df}=2.403\right.$, RMSEA $=$ $0.065, \mathrm{CFI}=0.90, \mathrm{NNFI}=0.90)$ of a good fit, as these values better recognized cut-off $(\chi 2 / \mathrm{df}<$ 3, RMSEA < 0.08, CFI > 0.95, NNFI > 0.95) (Bagozzi \& Yi, 1988; Browne \& Cudeck, 1993; $\mathrm{Hu} \&$ Bentler, 1999). Cheung and Rensvild (2002) postulated that the value of CFI and NNFI equivalent to 0.90 are acceptable.

We tested data reliability through composite reliability (CR). Table 2 indicates CR values of all variables which are greater than 0.70 . Thus, for further analysis our data is reliable (Kline, 2005). Additionally, the value of AVE must be greater than 0.5 for convergent validity and CR $\geq 0.70$. Table 2 also shows the value of AVE which indicates that our both results are acceptable and we achieved convergent validity (Hair, Anderson, Tatham, \& Black, 1995).

Table 2

Construct Reliability and Convergent Validity of Constructs Results

\begin{tabular}{lccc}
\hline Factor & $\begin{array}{c}\text { Composite Reliability } \\
\text { CR }>0.7\end{array}$ & Average Variance Extracted (AVE) $\geq 0.5$ & Square root AVE \\
\hline Abusive Supervision & .93 & .58 & .76 \\
Psychological Capital & .97 & .54 & .73 \\
Supervisor directed Deviance & .85 & .51 & .71 \\
Organization directed Deviance & .84 & .51 & .71 \\
\hline
\end{tabular}

The discriminant validity was examined through Fornell-Larcker criterion. The values of discriminant validity were obtained by comparing the value of AVE square root (oblique in parenthesis) and inter construct values. Table 3 indicates values of AVE square root which is greater than the correlation values of each variable (Kim \& Kim, 2010). Thus, these results confirm the discriminant validity of the study. Our results support the hypotheses of this study. Furthermore, the multicollinearity issue does not exist because the values of correlation coefficients are less than 0.70 (Tabachnick \& Fidell, 1996).

Table 3

Results of Discriminant Validity (Fornell-Larker Criterion)

\begin{tabular}{lllllll}
\hline & Mean & SD & 1 & 2 & 3 & 4 \\
\hline 1.Abusive Supervision & 1.75 & .78 & $\mathbf{( 0 . 7 6 )}$ & & & \\
2.Psychological Capital & 1.89 & .76 & -.077 & $\mathbf{( 0 . 7 3 )}$ & & \\
4.Supervisor directed Deviance & 1.99 & .50 & $.302^{* *}$ & -.073 & $(\mathbf{0 . 7 1 )}$ & $(\mathbf{0 . 7 1})$ \\
5.Organization directed Deviance 1.95 & .53 & $.283^{* *}$ & -.047 & $.350^{* *}$ & \\
\hline ** $\mathrm{p}<0.01$
\end{tabular}

\section{Hypothesis Testing}

For hypotheses evaluation, structural model technique was used as presented in Table 4. Our results indicate the fit indices values as a good fit $(\chi 2=1072.31$, df $=366, \chi 2 / \mathrm{df}=2.93$, RMSEA $=.07, \mathrm{CFI}=.90, \mathrm{NNFI}=.90)$, these values are good recommended cut-off $(\chi 2 / \mathrm{df}<3$, RMSEA <.08, CFI > .95, NNFI > .95) (Browne \& Cudeck 1993; Hu \& Bentler, 1999). To 
ensure the mediating role of positive PsyCap, the direct path (abusive supervision to interpersonal deviance) and indirect path (through positive psychological capital) are tested through two structural model (Iacobucci, Saldanha, \& Deng, 2007).

Table 4

Structural Model Results

\begin{tabular}{|c|c|c|c|c|c|c|}
\hline Hypotheses & \multicolumn{2}{|c|}{ Hypothesized Paths } & $\begin{array}{c}\text { Standardized Regression } \\
\text { Weights }(\beta)\end{array}$ & $t$ & $p$ & Results \\
\hline $\mathrm{H}_{1}$ & Abusive Supervision $\rightarrow$ & $\begin{array}{c}\text { Supervisor directed } \\
\text { deviance }\end{array}$ & .220 & 4.87 & $* * *$ & Accepted \\
\hline $\mathrm{H}_{2}$ & Abusive Supervision $\rightarrow$ & $\begin{array}{c}\text { Organization directed } \\
\text { deviance }\end{array}$ & .219 & 4.73 & $* * *$ & Accepted \\
\hline
\end{tabular}

As shown in Table $4, \mathrm{H}_{1}$ hypothesis $(\beta=.44, p<.001)$ supports that the abusive supervision positively relates to supervisor directed deviance. $\mathrm{H}_{2}$ hypothesis $(\beta=.44, p<.001)$ shows that the abusive supervision has a positive effect on organizational directed deviance.

\section{Moderation Analysis 1}

In this study, Baron and Kenny (1986) method has been used to check the moderating impact of positive psychological capital. The measurement model has been evaluated through fit indices. The results showed good fit values $\left(\chi^{2}=3.002, \mathrm{df}=2, \chi^{2} / \mathrm{df}=1.50, \mathrm{RMSEA}=.03\right.$, $\mathrm{NNFI}=.92, \mathrm{CFI}=.97$ )

Hypothesis 3 posits that positive psychological capital moderates the association between abusive supervision and supervisor directed deviance. If the positive psychological capital is high, it will weaken the relationship between abusive supervision and supervisor directed deviance, and it is supported. Table 5 shows that the standardized regression coefficients from interaction term are -.15 which is significant $(t=-5.44, p<.001)$. Figure 2 also displays moderating effect of positive psychological capital.

Table 5

Results of Moderation Analysis

\begin{tabular}{|c|c|c|c|c|c|c|c|}
\hline \multirow{3}{*}{ Hypotheses } & \multirow{2}{*}{\multicolumn{3}{|c|}{ Hypothesised Paths }} & \multirow{3}{*}{$\begin{array}{c}\text { Standardized } \\
\text { Regression Weights } \\
(\beta) \\
22\end{array}$} & \multirow{3}{*}{$\begin{array}{c}t \\
5.77\end{array}$} & \multirow{3}{*}{$\begin{array}{c}p \\
* * *\end{array}$} & \multirow{3}{*}{ Results } \\
\hline & & & & & & & \\
\hline & $\begin{array}{c}\text { Supervisor } \\
\text { directed Deviance }\end{array}$ & $\leftarrow$ & Abusive Supervision & & & & \\
\hline \multirow[t]{2}{*}{$\mathrm{H}_{3}$} & $\begin{array}{c}\text { Supervisor } \\
\text { directed Deviance }\end{array}$ & $\leftarrow$ & $\begin{array}{c}\text { Positive } \\
\text { Psychological } \\
\text { Capital }\end{array}$ & -.05 & -1.01 & $* * *$ & \multirow[t]{2}{*}{ Accepted } \\
\hline & $\begin{array}{c}\text { Supervisor } \\
\text { directed Deviance }\end{array}$ & $\leftarrow$ & Interaction & -.15 & -5.44 & $* * *$ & \\
\hline
\end{tabular}

*** Significance at $\mathrm{p}<0.001 * *$ significance at $\mathrm{p}<0.01 *$ significance at $\mathrm{p}<0.05$ 


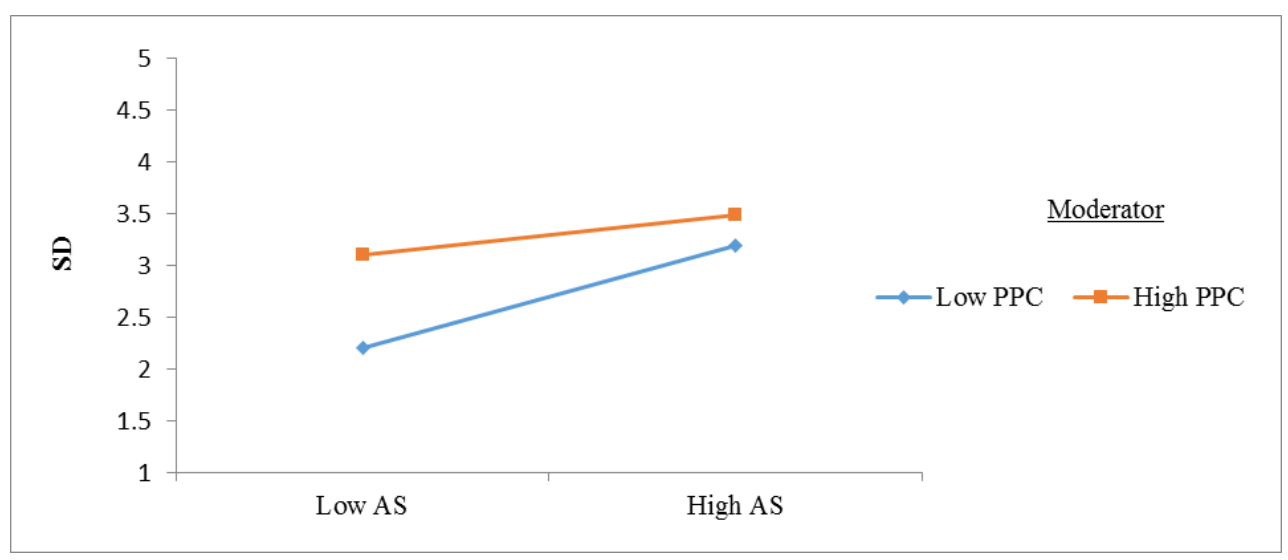

Figure 2. Moderating role of positive psychological capital

\section{Moderation Analysis 2}

The measurement model has been evaluated through fit indices. The results showed good fit values $\left(\chi^{2}=3.002, \mathrm{df}=2, \chi^{2} / \mathrm{df}=1.50, \mathrm{RMSEA}=.03, \mathrm{NNFI}=.91, \mathrm{CFI}=.97\right)$. Hypothesis 4 posits that positive psychological capital moderates the association between abusive supervision and organization directed deviance. If the positive psychological capital is high, it will weaken the relationship between abusive supervision and organization directed deviance and vice versa, and it is supported. Table 6 shows that the standardized regression coefficients from interaction term are -.17 which is significant $(t=-1.55, p<.001)$. Figure 3 also presents moderating effect of positive psychological capital.

Table 6

Results of Moderation Analysis

\begin{tabular}{|c|c|c|c|c|c|c|c|}
\hline \multirow{2}{*}{ Hypotheses } & \multicolumn{7}{|c|}{ Standardized } \\
\hline & \multicolumn{3}{|c|}{ Hypothesized Paths } & Regression Weights & $t$ & $p$ & Results \\
\hline \multirow{3}{*}{$\mathrm{H}_{4}$} & $\begin{array}{c}\text { Organization } \\
\text { directed Deviance }\end{array}$ & $\leftarrow$ & Abusive Supervision & .28 & 5.37 & $* * *$ & \multirow{3}{*}{ Accepted } \\
\hline & $\begin{array}{c}\text { Organization } \\
\text { directed Deviance }\end{array}$ & $\leftarrow$ & $\begin{array}{c}\text { Positive } \\
\text { Psychological Capital }\end{array}$ & -.02 & -4.89 & $* * *$ & \\
\hline & $\begin{array}{c}\text { Organization } \\
\text { directed Deviance }\end{array}$ & $\leftarrow$ & Interaction & -.17 & -1.55 & $* * *$ & \\
\hline
\end{tabular}

$* * *$ Significance at $\mathrm{p}<0.001 * *$ significance at $\mathrm{p}<0.01 *$ significance at $\mathrm{p}<0.05$

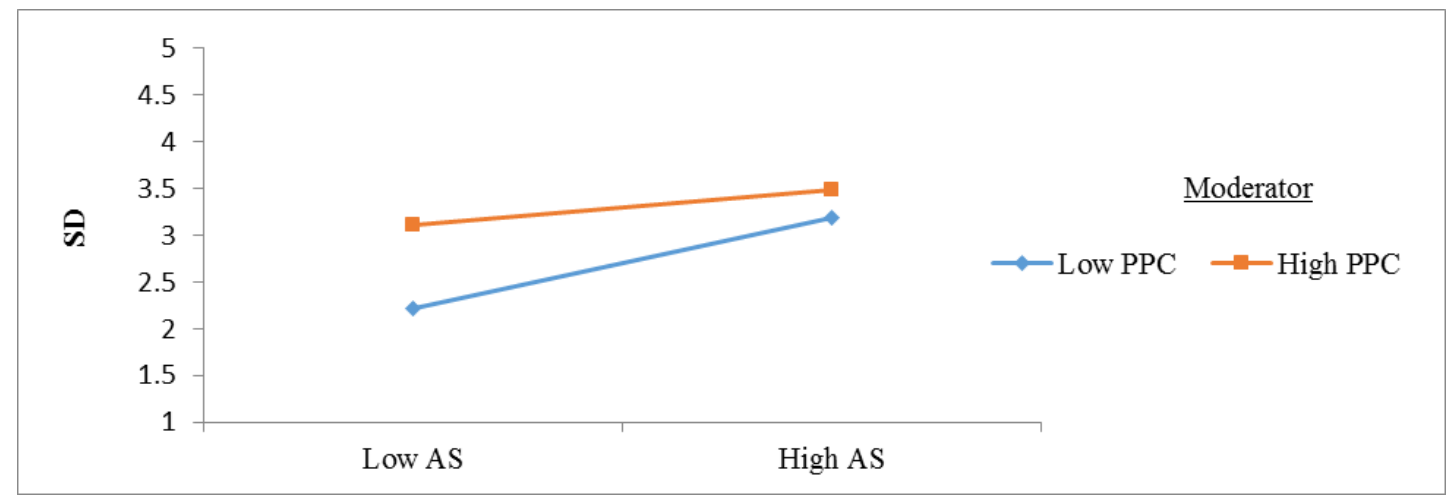

Figure 3. Moderating role of positive psychological capital 


\section{Discussion and Conclusion}

The main purpose of our study was not just to explore the negative impact of abusive supervision on subordinate's deviant behavior but also to investigate the moderating role of positive PsyCap in the proposed model. Indeed, Prior studies have focused on the linkage of abusive supervision and employee's negative behaviors in the western organizational context like Chinese, US (where high-power distance exhibit). However, we attained our study results in Pakistan organizational context where low power distance culture exhibit. In Chinese organizational context, Wang et al.'s (2012) study suggests that employees react more negatively when they experience abusive supervision under low power distance rather than high power distance culture.

Interestingly, our study outcomes show that abusive supervision directly influences subordinate's deviant behavior. There are multiple theories which help to recognize that how abusive supervision negatively impacts on employee's outcomes and how employees cope with these unwanted situations but primarily we support Social exchange theory and COR theory. At some extent, both theories suggest that at workplace employees not just reciprocate behavior either it is positive or negative but also exchange resources which influence entire organization. Depletion in employee resources is one of the costly problems of the organizations.

Empirical study's findings reported that demeaning language like abuse, publicly insult, and shout come from supervisor who depletes the employee's self-regulatory strength (Thau \& Mitchell, 2010; Wang et al., 2012). Self-regulation is one of the most important employee's resources that helps individuals to avoid violation of social norms and allows them to take selfcontrol of their emotions and thoughts (Bandura, 1991). If individuals are better in their selfregulatory state, they can develop good relationships and achieve job success (Vohs, Finkenauer, \& Baumeister, 2011). Likewise, positive psychological capital is another employee's personal resource which help to manage workplace uncertainties. Luthans and Youssef-Morgan (2017) defined PsyCap as it is related to individuals' positive emotions and personal resources like self-efficacy, optimism, and resilience and hope that help them to attain success. We also investigated mitigating effects of interpersonal mistreatment and employee's deviant behavior through the positive psychological capital, especially in Pakistan organizational context. The abusive supervision and deviant behavior relationship moderated by psychological capital. The relationship will be stronger if an individual has low positive psychological capital than high. This means that whenever employees experience mistreatment from their supervisor, they directly engage with deviant behavior like organizational deviance and supervisory deviance.

Consequently, an individual who has higher positive psychological capital would be less like to engage with deviant behavior and cope with abusive supervision. This is supported by Hu's (2012) study that individuals who have high emotional intelligence they have the ability to handle their emotions well even with the perception of abusive supervision. Raza, Moueed and Ali (2015) found the impact of management support for human resource development on employee job satisfaction. Lodhi and Ali (2017) found consumer reaction in cultural values. Raza, Ahmad and Ali (2016) studied strategic shift toward knowledge based educational management. Literature also indicate that there is no exclusive study examining mediating 
effects of positive psychological capital. However, previous study found a direct relationship of psychological capital with desirable behavior and attitude which reveals that employees who have psychological capital are satisfied and committed as a result they increase their performance and engage in citizenship behavior. The negative relationship with undesirable behavior and attitude shows that individuals who have low psychological capital are in stress and have anxiety and as a result turnover intention increases as well as they display workplace deviance (Avey et al., 2011). However, our results clearly support the suggested hypothesis that indicates PsyCap moderates between abusive supervision and individual's deviant behavior.

Finding negative consequences of abusive supervision is not only important but also challenging for developed and developing countries organizations. However, our research findings contribute to management literature by investigating the role of psychological capital among abusive supervision and workplace deviance. It provides deep understanding about employee's resources which help to cope with abusive supervision and their deviant behavior. This study indicates that every individual has a different level of PsyCap and handles the impact of abusive supervision and accordingly displays his/her deviant behavior. This means that an individual with high positive psychological capital easily copes with supervisory mistreatment and might not display aggressive behavior. This study also indicates that abusive supervision provides roots to deviant behavior. Therefore, organizations should adopt such ways that help them to eliminate undesirable behavior and stop abusive supervision from occurring. Our study findings also practically suggest that organizations should investigate the reasons behind supervisory mistreatment and work on their organizations HR polices. For example, organizations should design such kind of polices that support employee's psychological capital and reduce interpersonal mistreatments. Thau and Mitchell (2010) offer the solution of abusive supervision destructive effects as those who display abusive behavior should not appoint as a supervisor. Thau and Mitchell (2010) also suggest that supervisor training helps them to opt authentic leadership style. Organizations should create such a friendly atmosphere, build trust, and care about their employee's wellbeing. At some extent, these increase employee's psychological capital and eliminate the impact of interpersonal mistreatment like abusive supervision.

This study also acknowledged some limitations and future directions. Firstly, targeted participants only were taken from the pharmaceutical industry, Lahore, Pakistan. This means that results are not generalizable to other organizations. Participants were taken from Lahore region so that results are not generalizable to other regions.

Further data can be collected from multiple industries to evaluate the industrial effects by the suggested model. Secondly, we used the cross-sectional method to conduct this study so that future research can be cunducted by using the longitudinal method to find a relationship. Third, many other situational factors can be used as a moderator and mediator to study the relationship of abusive supervision and deviant behavior. Fourth, we used a positive PsyCap as a moderator to study the relationship. In future, the researcher can study other factors (reason) with abusive supervision like strict organizational polices, supervisory empowerment, etc. Finally, we used a single source to collect data. Therefore, employee's social desirability and 
self-serving may affect their rating. Future research should use multiple sources to collect data for deviance. Self-reporting technique may help to avoid the effects of social desirability.

Employees perceive that supervisors acts as organization agent, and they follow the top management instructions. In that case, they directly subrogate the organization's norms and involve in retaliation process. Therefore, this study clearly shows that subordinates display undesirable behavior to abusive supervisory behavior by involving in deviant behavior and take revenge from organization, supervisor and co-workers. Our research findings also revealed that PsyCap moderates the association of abusive supervision and deviant behavior. However, results also suggest that supervisor mistreatment hit the psychological state of subordinates.

\section{References}

Ali, M., Ahmad, Z., \& Iqbal, J. (2012). Human resource planning: A key to internal and external fit. African Journal of Business Management, 6(27), 7938-7941.

Ali, M., Lodhi, S. A., Raza, B., \& Ali, W. (2018). Examining the impact of managerial coaching on employee job performance: Mediating role of work engagement, leader-member-exchange quality, job satisfaction, and turnover intentions. Pakistan Journal of Commerce and Social Sciences, 12(1), 253-282.

Anderson, J. C., \& Gerbing, D. W. (1988). Structural equation modeling in practice: A review and recommended two-step approach. Psychological Bulletin, 103(3), 423-441.

Aquino, K., \& Douglas, S. (2003). Identity threat and antisocial behavior in organizations: The moderating effects of individual differences, aggressive modeling, and hierarchical status. Organizational Behavior and Human Decision Processes, 90(1), 195-208.

Aquino, K., Galperin, B. L., \& Bennett, R. J. (2004). Social status and aggressiveness as moderators of the relationship between interactional justices and workplace deviance. Journal of Applied Social Psychology, 34(5), 1001-1029.

Aquino, K., Tripp, T. M., \& Bies, R. J. (2006). Getting even or moving on? Power, procedural justices, and types of offense as predictors of revenge, forgiveness, reconciliation, and avoidance in organizations. Journal of Applied Psychology, 91(3), 653-668.

Ashforth, B. E. (1997). Petty tyranny in organizations: A preliminary examination of antecedents and consequences. Canadian Journal of Administrative Sciences/Revue Canadieene des Sciences del'Administration, 14(2), 126-140.

Avey, J. B., Luthans, F., \& Jensen, S. M. (2009). Psychological capital: A positive resource for combating employee stress and turnover. Human Resource Management, 48(5), 633-677.

Avey, J. B., Reichard, R. J., Luthans, F., \& Mhatre, K. H. (2011). Meta-analysis of impact of positive psychological capital on employee attitudes, behaviors, and performance. Human Resource Development Quarterly, 22(2), 127-152.

Avolio, B. J., Gardner, W. L., Walumbwa, F. O., Luthans, F., \& May, D. R. (2004). Unlocking the mask: A look at the process by which authentic leaders impact follower attitudes and behaviors. The Leadership Quarterly, 15(6), 801-823.

Bagozzi, R. P., \& Yi, Y. (1988). On the evaluation of structural equation model. Journal of the Academy of Marketing Science, 16(1), 74-94.

Bandura, A. (1991). Social cognitive theory of self-regulation. Organizational Behavior and Human Decision Processes, 50(2), 248-287.

Bakker, A. B., \& Demerouti, E. (2007). The job demands-resources model: State of the art. Journal of Managerial Psychology, 22(3), 309-328

Baron, R. M., \& Kenny, D. A. (1986). The moderator-mediator variable distinction in social psychological research: Conceptual, strategic, and statistical considerations. Journal of personality and social psychology, 51(6), 1173-1182.

Bennett, R. J., \& Robinson, S. L. (2000). Development of a measure of workplace deviance. Journal of Applied Psychology, $85(3), 349-360$.

Bennett, R. J., \& Robinson, S. L. (2003). The past, present, and future of workplace deviance research. In J. Greenberg (Ed.), Organizational behavior; The state of science (pp. 349-360). Erlbaum, Mahwah, NJ.

Bies, R. J., \& Tripp, T. M. (1996). Beyond distrust. Getting even and the need for revenge. In R. M. Karmer, \& T. R. Tyler (Eds.). Trust in Organization (pp. 246-260). Thousand Oaks, CA, US: Sage Publications, Inc.

Blau, P. (1964). Exchange and power in social life. New York: John Wiley and Sons.

Browne, M. W., \& Cudeck, R. (1993). Alternative ways of assessing model fil. Sage Focus Editions, 154, 136-136.

Byrne, A., Dionisi, A. M., Barling, J., Akers, A., Robertson, J., Lys, R.,... \& Dupré, K. (2014). The depleted leader: The influence of leaders' diminished psychological resources on leadership behaviors. The Leadership Quarterly, 25(2), 344 357.

Carlson, D., Ferguson, M., Hunter, E., \& Whitten, D. (2012). Abusive supervision and work-family conflict: The path through emotional labor and burnout. The Leadership Quarterly, 23(5), 849-859.

Cheung, G. W., \& Rensvold, R. B. (2002). Evaluating goodness-of-fit Indexes for testing measurement invariance. Structural Equation Modeling, 9(2), 233-255.

Colquitt, J. A., Conlon, D. E., Wesson, M. J., Porter, C. O., \& Ng, K. Y. (2001). Justice at the millennium: A meta-analysis review of 25 years of organizational justice research. Journal of Applied Psychology, 86(3), 425-445. 
Cropanzano, R., \& Mitchell, M. S. (2005). Social exchange theory: An interdisciplinary review. Journal of Management, $31(6), 874-900$.

Detert, J. R., Trevino, L. K., Burris, E. R., \& Andiappan, M. (2007). Managerial modes of influence and counterproductivity in organizations: A longitudinal business-unit-level investigation. Journal of Applied Psychology, 92(4), 993-1005.

Diefendorff, J. M., \& Mehta, K. (2007). The relations of motivational traits with workplace deviance. Journal of Applied Psychology, 92(4), 967-977.

Duffy, M. K., \& Ferrier, W. J. (2003). Birds of a feather...? How supervisor- subordinate dissimilarity moderates the influence of supervision behaviors on workplace attitudes. Group and Organization Management, 28(2), 217-248.

Foa, E. B., \& Foa, U.G. (1980). Resource theory social exchange: Advances in theory and research (pp. 77-94). Boston, MA: Springer.

Fornell, C., \& Larcker, D. F. (1981). Evaluating structural equation models with unobservable variables and measurement error. Journal of Marketing Research, 18(1), 39-50.

Fox, S., \& Spector, P. E. (1999). A model of work frustration-aggression. Journal of Organizational Behavior, $20(6), 915-931$.

Grandey, A. A., \& Cropanzano, R. (1999). The conservation of resources model applied to work-family conflict and strain. Journal of Vocational Behavior, 54(2), 350-370.

Gardner, W. L., \& Schermerhorn, J. R. (2004). Unleashing individual potential. Organizational Dynamics, 3(33), $270-281$.

Greenberg, J., \& Alge, B. J. (1998). Aggressive reactions to workplace injustice. Monographs in Organizational Behavior and Industrial Relations; Dysfunctional Behavior in Organization, 5, 83-117.

Hair, J. F., Anderson, R. E., Tatham, R. L., \& Black, W. C. (1995). Multivariate data analyses with readings. New Jersey: Englewood Cliffs.

Hobfoll, S. E. (2001). The influence of culture, community, and the nested-self in the stress process: Advancing conservation of resources theory. Applied Psychology, 50(3), 337-421.

Hamid, R. A., Juhdi, N. H., Ismail, M. D., \& Abdullah, N. A. (2017). Abusive supervision and workplace deviance as moderated by spiritual intelligence; An empirical study of Selangor employees. Geografia-Malaysian Journal of Society and Space, 12(2), 191-202.

Halbesleben, J. R. (2011). Sources of social Support and burnout: A meta-analysis test of the conservation of resource model. Journal of Applied Psychology, 91(5), 1134-1145.

Hershcovis, M. S., Turner, N., Barling, J., Arnold, K. A., Dupre, K. E., Inness, M., \& Sivanathan, N. (2007). Predicting workplace aggression: A meta-analysis. Journal of Applied Psychology, 92(1), 228-238.

Hobman, E. V., Restubog, S. L. D., Bordia, P., \& Tang, R. L. (2009). Abusive supervision in advising relationships: Investigating the role of social support. Applied Psychology, 58(2), 233-256.

$\mathrm{Hu}, \mathrm{H}$. H. (2012). The influence of employee emotional intelligence on coping with supervisor abuse in a banking context. Social Behavior and Personality: An International Journal, 40(5), 863-874.

Hu, L. T., \& Bentler, P. M. (1999). Cutoff criteria for fit indexes in covariance structure analysis: Conventional criteria versus new alternatives. Structural equation modeling: A Multidisciplinary Journal, 6(1), 1-55.

Iacobucci, D., Saldanha, N., \& Deng, X. (2007). A meditation on mediation: Evidence that structural equations models perform better than regressions. Journal of Consumer Psychology, 17(2), 139-153.

Ilies, R., Morgeson, F. P., \& Nahrgang, J. D. (2005). Authentic leader and eudemonic well-being: Understanding leaderfollower outcomes. The Leadership Quarterly, 16(3), 373-394.

Jones, D. A. (2009). Getting even with one's supervisor and one's organization: Relationships among types of injustice, desires for revenge, and counterproductive work behaviors. Journal of Organizational Behavior: The International Journal of Industrial, Occupational and Organizational Psychology and Behavior, 30(4), 525-542.

Jones, R. J., Woods, S. A., \& Guillaume, Y. R. (2016). The effectiveness of workplace coaching: A meta- analysis of learning and performance outcomes from coaching. Journal of Occupational and Organizational Psychology, 89(2), $249-277$.

Judge, T. A., \& Bono, J. E. (2001). Relationship of core self-evaluations traits- self- esteem, generalized self-efficacy, Locus of control, and emotional stability- with job satisfaction and job performance: A meta-analysis. Journal of Applied Psychology, 86(1), 80-92.

Kim, M. G., \& Kim, J. (2010). Cross-validation of reliability, convergent and discriminant validity for the problematic online game use scale. Computers in Human Behavior, 26(3), 389-398.

Kim, S., \& Kuo, M. H. (2015). Examining the relationships among coaching, trustworthiness, and role behaviors: A social exchange perspective. The Journal of Applied Behavioral Science, 51(2), 152-176.

Kline, R. B. (2005). Principles and practice of structural equation modeling, 2nd edition. New York: Guilford Press.

Kluemper, D. H., Mossholder, K. W., Ispas, D., Bing, M. N., Iliescu, D., \& Ilie, A. (2018). When core self-evaluations influence employees' deviant reactions to abusive supervision: The Moderating role of cognitive ability. Journal of Business Ethics, 1-19.

Lazarus, R. S., \& Folkman, S. (1987). Transactional theory and research on emotions and coping. European Journal of Personality, 1(3), 141-169.

Li, Y., Wang, Z., Yang, L. Q., \& Liu, S. (2016). The crossover of psychological distress from leaders to subordinates in teams: The role of abusive supervision, Psychological capital and team performance. Journal of Occupational Health Psychology, 21(2), 142-153.

Lian, H., Ferris, D. L., Morrison, R., \& Brown, D. J. (2014). Blame it on the supervisor or the subordinate? Reciprocal relations between abusive supervision and organizational deviance. Journal of Applied Psychology, 99(4), 651-664.

Lind, E. A., \& Van den Bos, K. (2002). When Fairness works: Toward a general theory of uncertainty management. Research in Organizational Behavior, 24, 181-223.

Lodhi, S. A., \& Ali, M. (2017). Consumer Reaction: Linking Consumer Associations and Cultural Values. Pakistan Journal of Commerce \& Social Sciences, 11(2), 720-736. 
Luthans, F., Avolio, B. J., Avey, J. B., \& Norman, S. M. (2007). Positive psychological capital: Measurement and relationship with performance and satisfaction. Personnel Psychology, 60(3), 541-572.

Luthans, F., Norman, S. M., Avolio, B. J., \& Avey, J. B. (2008). The mediating role of psychological capital in the supportive organizational climate-employee performance relationship. Journal of Organizational Behavior: The International Journal of Industrial, Occupational and Organizational Psychology and Behavior, 29(2), 219-238.

Luthans, F., \& Youssef-Morgan, C. M. (2017). Psychological capital: An evidence-based positive approach. Annual Review of Organizational Psychology and Organizational Behavior, 4, 339-366.

Martinko, M. J., Harvey, P., Brees, J. R., \& Mackey, J. (2013). A review of abusive supervision research. Journal of Organizational Behavior, 34(S1), 120-137.

Michel, J. S., Newness, K., \& Duniewicz, K. (2016). How abusive supervision affects workplace deviance: A ModeratedMediation examination of aggressiveness and work-related negative affect. Journal of Business and Psychology, 31(1), 122.

Mitchell, M. S., \& Ambrose, M. L. (2007). Abusive supervision and workplace deviance and the moderating effects of negative reciprocity beliefs. Journal of Applied Psychology, 92(4), 1159-1168.

Neuman, J. H., \& Baron, R. A. (1998). Workplace violence and workplace aggression: Evidence concerning specific forms, potential causes, and preferred targets. Journal of Management, 24(3), 391-419.

Newman, A., Nielsen, I., Smyth, R., \& Hirst, G. (2018). Mediating role of psychological capital in the relationship between social support and wellbeing of refugees. International Migration, 56(2), 117-132.

Park, H., Hoobler, J. M., Wu, J., Liden, R. C., Hu, J., \& Wilson, M. S. (2017). Abusive supervision and employee deviance: A multifocal justice perspective. Journal of Business Ethics, 1-9.

Rafferty, A. E., Restubog, S. L. D., \& Jimmieson, N. L. (2010). Losing sleep: Examining the cascading effects of supervisors' experience of injustice on subordinates' psychological health. Work \& Stress, 24(1), 36-55.

Raza, A., Ahmad, E. Ali, M. (2016). Strategic shift towards knowledge-based educational management in Pakistan. Business Review, 11(2), 33-40.

Raza, B., Ali, M., Ahmed, S., \& Ahmad, J. (2018). Impact of managerial coaching on organizational citizenship behavior: The mediation and moderation model. International Journal of Organizational Leadership, 7(1), 27-46.

Raza, B., Ali, M., Ahmed, S., \& Moueed, A. (2017). Impact of managerial coaching on employee performance and organizational citizenship behavior: Intervening role of thriving at work. Pakistan Journal of Commerce \& Social Sciences, 11(3), 790-813.

Raza, B., Ali, M., Naseem, K., Moeed, A., Ahmed, J., \& Hamid, M. (2018). Impact of trait mindfulness on job satisfaction and turnover intentions: Mediating role of work-family balance and moderating role of work-family conflict. Cogent Business and Management, 5(1), 1-20.

Raza, B., Moueed, A., \& Ali, M (2015). The impact of management support for human resource development on employee job satisfaction: A study of public sector colleges in Lahore. Science International, 27(5), 4689-4695.

Raza, B., Moueed, A., Ali, M. (2018). Impact of managerial coaching on employee thriving at work: The moderating role of perception of organizational politics. Journal of Business Strategies, 12(1), 87-108.

Restubog, S. L. D., Scott, K. L., \& Zagenczyk, T. J. (2011). When distress hits home: the role of contextual factors and psychological distress in predicting employees' responses to abusive supervision. Journal of Applied Psychology, 96(4), 713-729.

Robinson, S. L., \& Bennett, R. J. (1995). A typology of deviant behaviors: A multidimensional scaling study. Academy of Management Journal, 38(2), 555-572.

Robinson, S. L., \& Greenberg, J. (1998). Employees behaving badly: Dimensions, determinants and dilemmas in the study of workplace deviance. Journal of Organizational Behavior (1986-1998), 5, 1-30.

Roberts, S. J., Scherer, L. L. \& Bowyer, C. J. (2011). Job stress and incivility: What role does psychological capital play? Journal of Leadership and Organizational Studies, 18(4), 449-458.

Selye, H. (1974). Stress without distress. Philadelphia: New York.

Skarlicki, D. P., \& Folger, R. (2004). Broadening our understanding of organizational retaliatory behavior. The Dark Side of Organizational Behavior, 373-402.

Skarlicki, D. P., Folger, R., \& Tesluk, P. (1999). Personality as a moderator in the relationship between fairness and retaliation. Academy of Management Journal, 42(1), 100-108.

Spector, P. E., Fox, S., Penney, L. M., Bruursema, K., Goh, A., \& Kessler, S. (2006). The dimensionality of counterproductivity: Are all counterproductive behaviors created equal? Journal of Vocational Behavior, 68(3), 446-460.

Tepper, B. J. (2000). Consequences of abusive supervision. Academy of Management Journal, 43(2), 178-190.

Tepper, B. J., Duffy, M. K., Hoobler, J., \& Ensley, M. D. (2004). Moderators of the relationships between coworkers' organizational citizenship behavior and fellow employees' attitudes. Journal of Applied Psychology, 89(3), 455-465.

Tepper, B. J., Duffy, M. K., \& Shaw, J. D. (2001). Personality moderators of the relationship between abusive supervision and subordinates' resistance. Journal of Applied Psychology, 85(5), 974-983.

Tepper, B. J., Henle, C. A., Lambert, L. S., Giacalone, R. A., \& Duffy, M. K. (2008). Abusive supervision and subordinates' organization deviance. Journal of Applied Psychology, 93(4), 721-732.

Tabachnick, B., \& Fidell, L. (1996). Using multivariate statistics, 3rd edition. New York: Harper Collins.

Thau, S., Bennett, R. J., Mitchell, M. S., \& Marrs, M. B. (2008). How management style moderates the relationship between abusive supervision and workplace deviance: An uncertainty management theory perspective. Organizational Behavior and Human Decision Processes, 108(1), 79-92.

Thau, S. \& Mitchell, M. S. (2010). Self-gain or self-regulation impairment? Tests of competing explanations of the supervisor abuse and employee deviance relationship through perceptions of distributive justice. Journal of Applied Psychology, 95(6), $1009-1031$. 
Vander Elst, T., De Cuyper, N., Baillien, E., Niesen, W., \& De Witte, H. (2016). Perceived Control and psychological contract breach as explanations of the relationships between job insecurity, Job Strain and coping reactions: Towards a theoretical integration. Stress and Health, 32(2), 100-116.

Vohs, K. D., Finkenauer, C., \& Baumeister, R. F. (2011). The sum of friends' and lovers' self-control score predicts relationship quality. Social Psychological and Personality Science, 2(2), 138-145.

Wang, H., Sui, Y., Luthans, F., Wang, D., \& Wu, Y. (2014). Impact of authentic leadership on performance: Role of followers' positive psychological capital and relational processes. Journal of Organizational Behavior, 35(1), 5-21.

Wang, W., Mao, J., Wu, W., \& Liu, J. (2012). Abusive supervision and workplace deviance: The mediating role of interactional justice and the moderating role of power distance. Asia Pacific Journal of Human Resources, 50(1), 43-60.

Wright, T. A., \& Cropanzano, R. (1998). Emotional exhaustion as predictor of job performance and voluntary turnover. Journal of Applied Psychology, 83(3), 486-493.

Zellars, K. L., Tepper, B. J., \& Duffy, M. K. (2002). Abusive supervision and subordinates' organizational citizenship behavior. Journal of Applied Psychology, 87(6), 1068-1076. 